\title{
ARIZONA BIRD COMMITTEE REPORT, 2018-2020 RECORDS
}

GARY H. ROSENBERG, P. O. Box 91856, Tucson, Arizona, 85752-1856

ghrosenberg@comcast.net

KURT RADAMAKER, 6132 E Morning Vista Lane, Cave Creek, Arizona, 85331

ABSTRACT: From 2018 to 2020 the Arizona Bird Committee reviewed 195 reports and updated the Arizona bird list through 2020, adding two species-the White-throated Thrush (Turdus assimilis) and Clay-colored Thrush (Turdus grayi) bringing the Arizona state list to 567 species in good standing.

This is the 10th published report of the Arizona Bird Committee (ABC) (Speich and Parker 1973, Speich and Witzeman 1975, Rosenberg and Witzeman 1998, 1999, Rosenberg 2001, Rosenberg et al. 2007, 2011, 2017, 2019). This report covers records from 2018 to the end of 2020 and includes some records from prior years reviewed during that interval. The $\mathrm{ABC}$ reviewed a total of 195 reports, of which 184 (94\%) became accepted records. Two different White-throated Thrushes (Turdus assimilis) and a Clay-colored Thrush ( T. grayi) added two species to the Arizona state list-bringing it to 567 species in good standing.

Other highlights in this report include acceptance of Arizona's third Eurasian Green-winged Teal (Anas crecca crecca), second Common Crane (Grus grus), sixth and seventh Northern Jacanas (Jacana spinosa), second Black Turnstone (Arenaria melanocephala), fifth and sixth Sharp-tailed Sandpipers (Calidris acuminata), 10 different Lesser Black-backed Gulls (Larus fuscus) - nearly doubling the number of state records, seventh Arctic Tern (Sterna paradisaea), fifth Blue-headed Vireo (Vireo solitarius), fifth Carolina Wren (Thryothorus ludovicianus), two Gray-crowned Rosy-Finches (Leucosticte tephrocotis), representing a third state record, two flocks of Black Rosy-Finches (L.atrata), representing the seventh and eighth records, and seventh through ninth Field Sparrows (Spizella pusilla), as well as four different Tropical Parulas (Setophaga pitayumi) and four different Canada Warblers (Cardellina canadensis).

The current Arizona Bird Committee (2021) consists of Chris D. Benesh (who serves as chair), Troy Corman, Sean Fitzgerald, Felipe Guerrero, Lauren Harter, Keith Kamper, Ryan O'Donnell, and David Vander Pluym. Recent committee members who also voted on records in this report include Andrew Core, Eric Hough, Scott Olmstead, Kurt Radamaker (who is also our web master), Magill Weber, and Gary H. Rosenberg (who serves also as secretary). Janet Witzeman serves in a nonvoting capacity as assistant secretary, as she has done since the committee began in the early 1970 s.

The ABC's web site (http://abc.azfo.org) includes the Arizona state list, a list of species currently reviewed, the ABC's bylaws, a list of current committee members, a brief history of the $\mathrm{ABC}$, an electronic form for reporting, and all past reports of the $\mathrm{ABC}$ (as published in Western Birds). When a species is removed from the $\mathrm{ABC}$ review list, we mention that information in the species accounts in the reports, as well as in the "News" of the committee.

The $\mathrm{ABC}$ encourages observers to submit documentation for species on 
the review list, as well as for species new to Arizona. All material should be submitted via http://abc.azfo.org or sent to Rosenberg at the address above. The committee would like to emphasize the importance of submitting documentation of sightings directly to the ABC for review. The posting of reports, including those with written descriptions, on local "listservs" and at www.eBird.org may not be assumed to have been discovered by the $\mathrm{ABC}$, nor be assumed to be intended as documentation of a rarity. The $\mathrm{ABC}$ prefers reports submitted directly to the committee. The ABC thanks the many observers $(180+)$ who have submitted their documentation of sightings to the Arizona Field Ornithologists (AZFO) and ABC for this report. Each record listed below includes a locality, county (abbreviations: see below), date span, and initial observer if known. Additional observers who submitted written reports (as indicated by the symbol $\dagger$ ), photographs, video recordings, and sound recordings are also listed. All records are of sight reports unless noted otherwise with a symbol for a photograph, sound recording, or specimen (abbreviations: see below). As of 2021 the ABC's current policy is to review reports of birds recurring in successive years only if the bird has departed and then returned. Reports of individual birds that persist for multiple years without leaving are not reviewed after the initial acceptance. In most cases, the total number of Arizona records for a species includes the number of records accepted by the ABC plus those published in Birds of Arizona (Phillips et al. 1964) or in the Annotated Checklist of the Birds of Arizona (Monson and Phillips 1981). The ABC emphasizes that a report listed under "reports not accepted" means that the documentation supplied was insufficient and/ or did not meet the standards of the committee for substantiation.

Abbreviations for Arizona counties are APA, Apache; COS, Cochise; COC, Coconino; GIL, Gila; GRA, Graham; GRE, Greenlee; LAP, La Paz; MAR, Maricopa; MOH, Mohave; NAV, Navajo; PIM, Pima; PIN, Pinal; SCR, Santa Cruz; YAV, Yavapai; YUM, Yuma. Other abbreviations used include $\dagger$, written description; ph., photograph; s.r., sound recording; v.r., video recording; NM, National Monument; NRA, National Recreation Area; NWR, National Wildlife Refuge; SP, State Park; WMA, Wildlife Management Area. The finder of a bird who also submitted details is acknowledged first; other observers who submitted details follow.

Of the numbers appearing in parentheses $(n, n, n)$ after each species' name, the first represents the total number of reports published by Phillips et al. (1964) or Monson and Phillips (1981) that the ABC considers correct but has not formally reviewed, provided the species was included on the ABC's first (1972) checklist. (The "\#” symbol denotes a species not recognized or not on the review list at that time.) The second number is the number of records accepted by the $\mathrm{ABC}$ from 1972 until this report, and the third number is the number of records of the species published in this report. For example, in the case of the Red-eyed Vireo, $(5,43,3)$ signifies that five records were published in Birds of Arizona, 43 records were accepted and published in previous $\mathrm{ABC}$ reports, and three others are published in this report. All totals reflect the number of reports and not the number of individual birds (e.g., 200 Least Storm-Petrels at Lake Havasu, MOH, after Tropical Storm Nora on 26 September 1997 constitute one record. 


\section{ARIZONA BIRD COMMITTEE REPORT, 2018-2020 RECORDS}

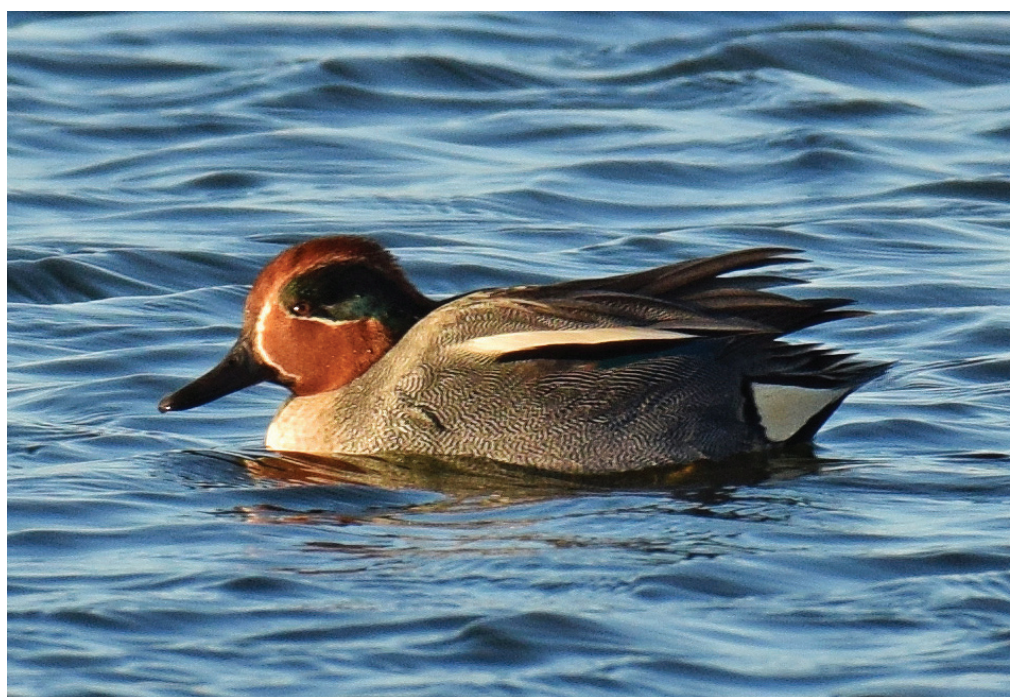

Figure 1. This adult male Eurasian Green-winged Teal in Phoenix, Maricopa Co., 3 Jan 2019 provided only the third Arizona record of this form.

Photo by Ryan P. O’Donnell

\section{HISTORICAL RECORDS}

Several species on the Arizona list are founded on specimen records of species that have not occurred since being published by Phillips et al. (1964). These include the Eastern Whip-poor-will (Antrostomus vociferus), Bumblebee Hummingbird (Selasphorus heloisa), Anhinga (Anhinga anhinga), Whitetailed Hawk (Geranoaetus albicaudatus), Aplomado Falcon (Falco femoralis),

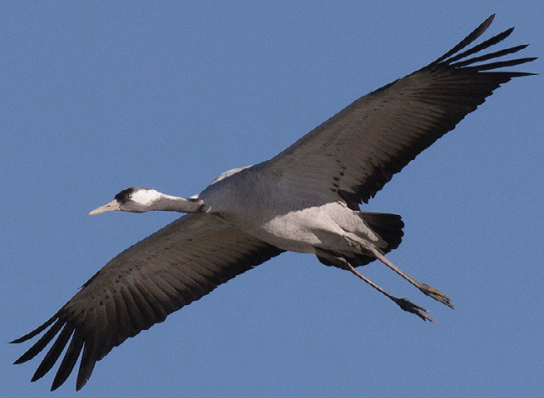

Figure 2. Arizona's second Common Crane accompanied Sandhill Cranes at Willcox, Cochise Co., 28-29 Nov 2020. 


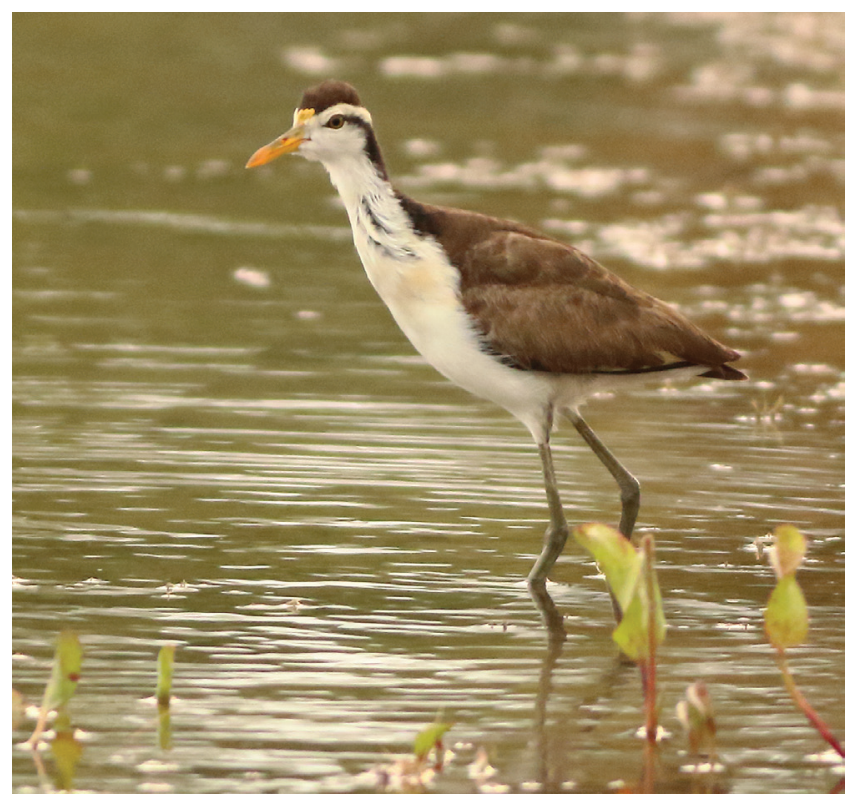

FIgURE 3. Arizona's sixth Northern Jacana was this immature on a golf course in Green Valley, Pima Co., and subsequently at nearby Canoa Ranch, 9-11 Sep 2020.

Photo by Patricia Isaacson

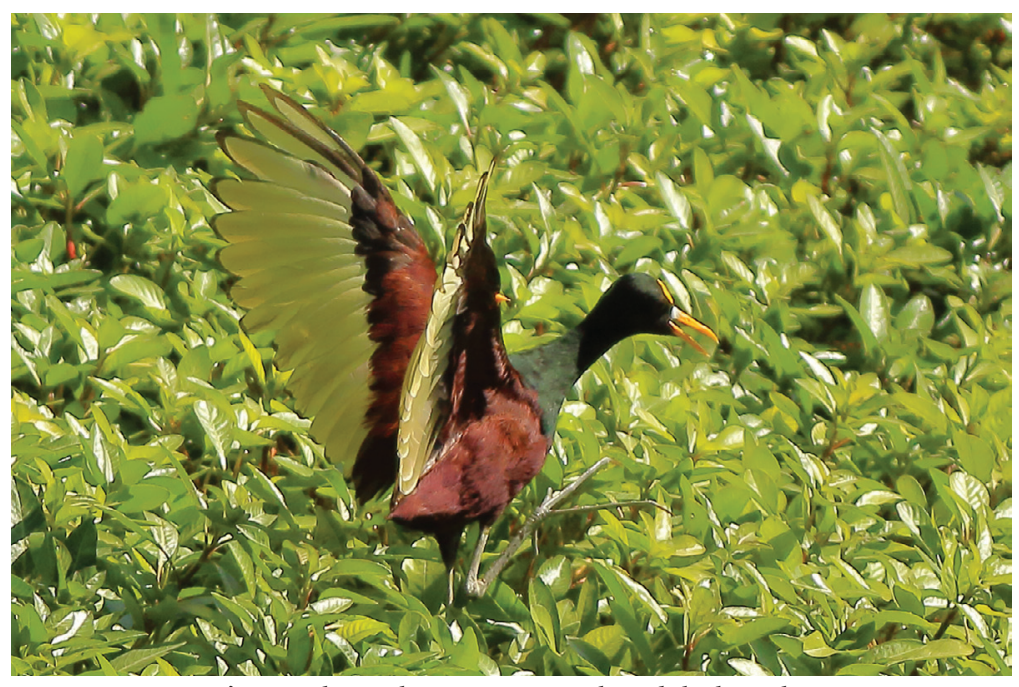

Figure 4. Arizona's seventh Northern Jacana was this adult along the Santa Cruz River in Tucson, Pima Co., from 26 Sep 2020 through at least 9 Apr 2021.

Photo by Patricia Isaacson 
Thick-billed Parrot (Rhynchopsitta pachyrhyncha), Acadian Flycatcher (Empidonax virescens), and Gray-cheeked Thrush (Catharus minimus). These species have been grandfathered onto the ABC's list. Also in this category are two extirpated species, the Masked Northern Bobwhite (Colinus virginianus ridgwayi) and California Condor (Gymnogyps californianus), which have both been reintroduced into Arizona, but neither has yet become established.

Other species listed as hypothetical by Phillips et al. (1964) or Monson and Phillips (1981) were based on undocumented sight reports or were presumed by the $\mathrm{ABC}$ to be likely escapees. These include the Greater Sage Grouse (Centrocercus urophasianus), Yellow Rail (Coturnicops noveboracensis), Black Oystercatcher (Haematopus bachmani), American Woodcock (Scolopax minor), Great Frigatebird (Fregata minor), Scarlet Ibis (Eudocimus ruber), Snowy Owl (Bubo scandiacus), Pileated Woodpecker (Dryocopus pileatus), San Blas Jay (Cyanocorax sanblasianus), and Orange-billed Nightingale-Thrush (Catharus aurantiirostris). These species are not on the ABC's Arizona state list, and they have not been reviewed by the ABC.

\section{EXOTICS}

Several species of exotics are accepted on the basis of their having been introduced (or having arrived on their own from other introduced populations) and having been established for $\geq 15$ years (see American Birding Association criteria for determining establishment of exotics; https://www.aba. org/criteria-for-determining-establishment-of-exotics/). These include the California Quail (Callipepla californica), Ring-necked Pheasant (Phasianus colchicus), Chukar (Alectoris chukar), Rock Pigeon (Columba livia), Eurasian Starling (Sturnus vulgaris), and House Sparrow (Passer domesticus). The California Quail, Ring-necked Pheasant, and Chukar were added to the list on the basis of information in Arizona Game Birds (Brown 1989). Two additional exotics have been accepted, the Eurasian Collared-Dove (Streptopelia decaocto), which arrived in the state on its own and is now abundant, and the Rosy-faced Lovebird (Agapornis roseicollis), which was originally released or escaped from captivity and is well established in the Phoenix area (see http:// arizonabirds.org/sites/default/files/articles/arizona-birds-status-rosy-facedlovebird-phoenix-arizona_0.pdf). The ABC is currently monitoring other exotic species such as the Monk Parakeet (Myiopsitta monachus) as potential additions to the state list.

\section{ACCEPTED REPORTS}

FULVOUS WHISTLING-DUCK Dendrocygna bicolor $(6,11,2)$. One was at the Green Valley wastewater-treatment plant, PIM, 25 Jul-30 Aug 2018 (ph. CMC, CMG); one was at Canoa Ranch, PIM, 8 Sep 2020 (JH). Formerly a regular visitor to southern Arizona and a breeding summer resident in southern California, this species has declined and is now only a casual and irruptive visitor (Monson and Phillips 1981, Hamilton et al. 2007) with most recent reports in winter.

BRANT Branta bernicla $(2,16,1)$. One record of two at Roper Lake SP, GRA, 21 Nov 2019 (ph. KW). Both individuals were Black Brant (B. b. nigricans), like all 
of Arizona's Brant previously identified to subspecies. This species remains a casual fall and winter visitor to the state.

TRUMPETER SWAN Cygnus buccinator $(0,9,2)$. One immature was at Shield Ranch near Camp Verde, YAV, 2 Jan 2019 (ph. KH, LG, KR); one adult was at Peck's Lake, YAV, 17 Feb-8 Mar 2019 (ph. SH). One immature photographed at the Phoenix Zoo, MAR, 14 Jan 2018 (ph. KWa) is under further review. The number of records in Arizona continues to increase; the $\mathrm{ABC}$ continues to regard this species' occurrence in Arizona a result of birds dispersing from "wild" populations (see Rosenberg et al. 2007), unless records can be linked to a relocation program.

EURASIAN GREEN-WINGED TEAL Anas crecca crecca $(0,2,1)$. One adult male was discovered at the Phoenix Federal Prison, MAR, 3 Jan 2019 (ph. ROD; Figure 1), providing a third Arizona record of this form.

BLACK SCOTER Melanitta americana $(0,31,6)$. Accepted records are of one at the Bill Williams delta, MOH, 4 Nov 2018 ( $† \mathrm{RA}$; $\nmid \mathrm{LHa}$ ); a different bird below Parker Dam, LAP, 4 Nov 2018-12 Feb 2019 (†, ph. DVP; $\dagger$, ph. LHa); an adult male at the north end of Lake Havasu, MOH, 13 Apr 2019 ( $†$ DWK); a female at a pond lined with plastic $7 \mathrm{~km}$ west of Wellton, YUM, 16 Oct 2019 ( $\dagger$, ph. BJ); an immature at Lake Havasu City, MOH, 21 Oct-22 Dec 2019 (†DVP); and one male on Lake Pleasant, MAR, 23-28 Jan 2020 (ph. MVW). During the past decade this species has become more regular in Arizona (see Rosenberg et al. 2017) and elsewhere in the Southwest, including Nevada (Tinsman and Meyers 2019). The ABC discontinued the Black Scoter as a review species in January 2020.

LEAST GREBE Tachybaptus dominicus $(4,21,4)$. A previously unreported bird was at Bear Grass Tank, near Tucson, PIM, 2 Jan 2017 (ph. PS). Other records include single birds at Patagonia Lake SP, SCR, 28-29 Mar 2018 (KHe; ph. ES, CM) and (likely the same bird) 10 May 2018 (ph. BL); one at Peña Blanca Lake, SCR, 23 Aug 2019 (†, ph. SA); and one at Quitobaquito, Organ Pipe NM, PIM, 1 Mar 2020 $(\dagger$, ph. CH; ph. RT). Despite nesting in Arizona at Peña Blanca Lake 2010-2012, and scattered records there up to April 2014 (see Rosenberg et al. 2017), this species remains a casual and irregular visitor and has yet to become established as a regular breeding species in the state.

GROOVE-BILLED ANI Crotophaga sulcirostris $(3,25,4)$. One was at a residence about $8 \mathrm{~km}$ northeast of Arivaca, PIM, 14 Jun 2018 ( $\dagger$, ph. KG); one was at Whitewater Draw WMA, COS, 10 Jul-7 Aug 2018 (†, ph. LHa; ph. KM); one was at the Patagonia-Sonoita Creek Preserve outside Patagonia, SCR, 6 Jul 2019 ( $\dagger$, ph. $\mathrm{KWe}$ ); and one was at St. David, COS, 31 Oct 2020 ( $\dagger$, ph. MM). There are now more than 30 Arizona records, so the $\mathrm{ABC}$ has removed this species from the review list.

BUFF-COLLARED NIGHTJAR Antrostomus ridgwayi (5, 14, 3). Accepted records are of one calling at Mineral Creek near Superior, PIN, 27 Jun 2017 (s.r. MB); up to four individuals at California Gulch, SCR, 16 Apr-16 Aug 2018 (†SK; ph. LH; ph. PO); and at least two in Brown Canyon, Buenos Aires NWR, PIM, 11 Jun 2018 $(\dagger$, s.r. CC). Reports have increased in recent years, and the species has become regular (presumably breeding) at the bottom of California Gulch, Brown Canyon, and likely elsewhere in the Atascosa and Santa Rita Mountains, As a result, the ABC has removed this species from the review list.

BLACK SWIFT Cypseloides niger (3, 6, 2). Well-described birds were in Phoenix, MAR, 16 Apr 2018 (†AK) and in South Fork of Cave Creek Canyon near Portal, COS, 4 Aug 2018 ( $† \mathrm{GK}$ ). There is just one Arizona specimen (see Rosenberg et al. 2019), and no photographs of living birds.

CHIMNEY SWIFT Chaetura pelagica $(2,1,2)$. One well described and photographed along the Little Colorado River near Cameron, COC, 19 May2018 ( $\dagger$, ph. 


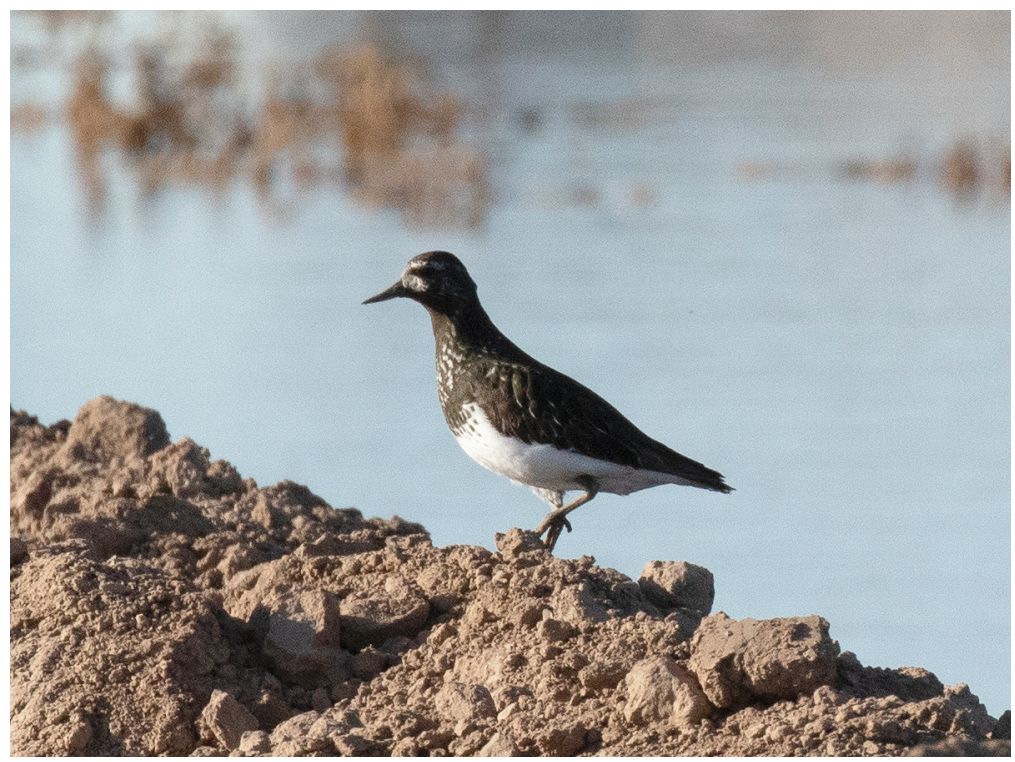

Figure 5. This Black Turnstone in Yuma, Yuma Co., 13 May 2020 represented only the second record for Arizona.

Photo by Gary H. Rosenberg

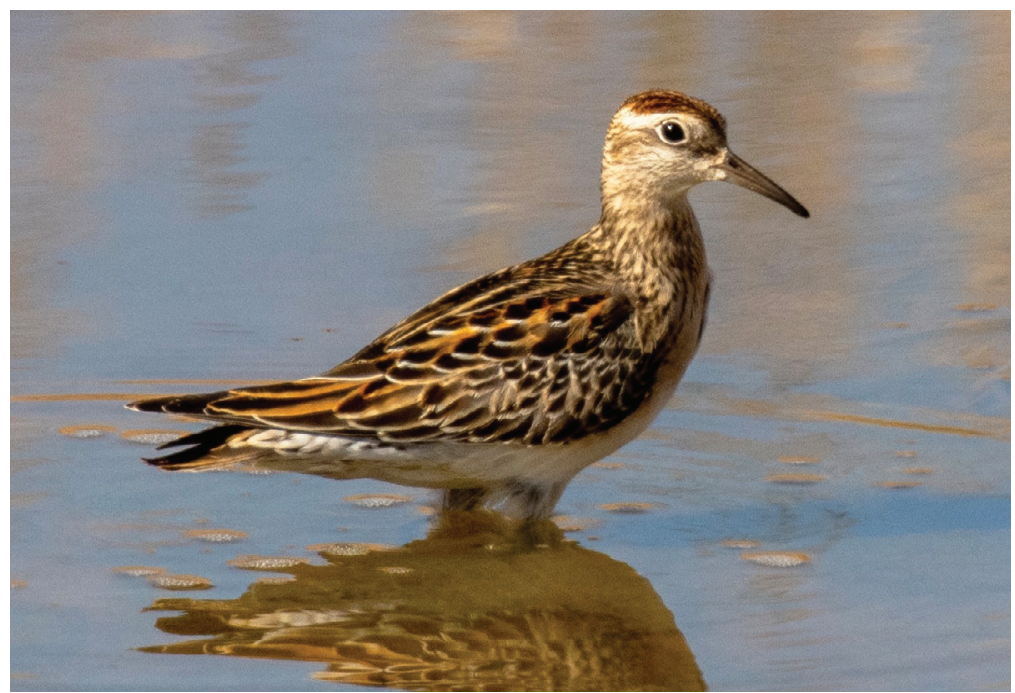

Figure 6. Arizona's sixth Sharp-tailed Sandpiper was this juvenile at Spot Road Farm, Yuma Co., 29 Oct 2020.

Photo by Derik Bowen 


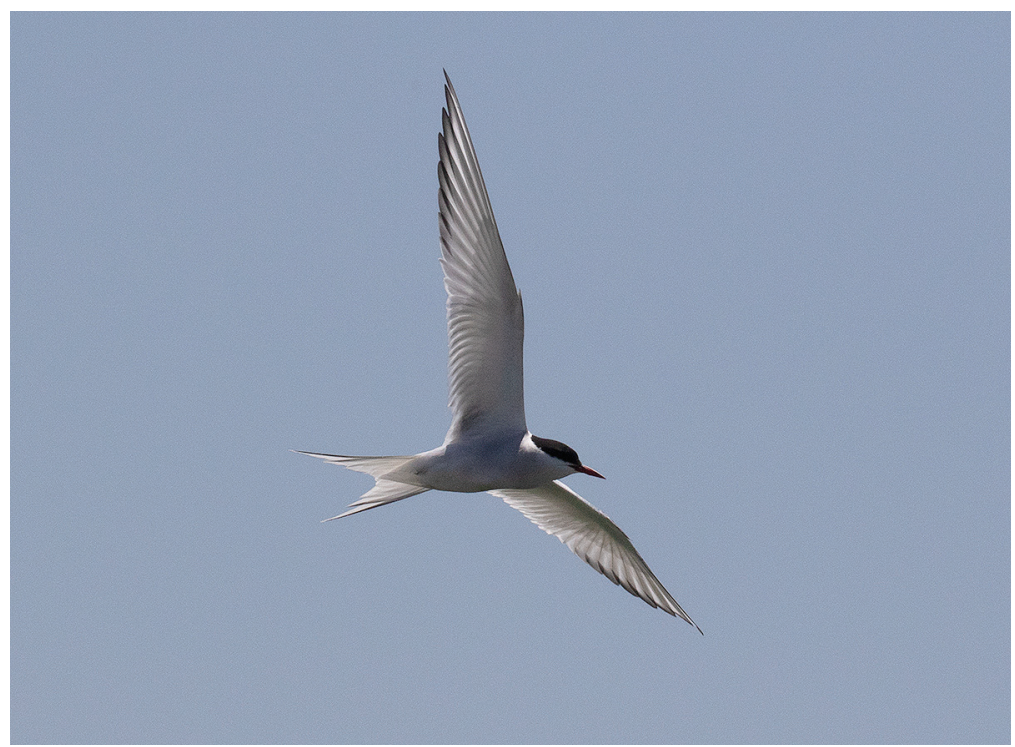

Figure 7. Arizona's first photographed Arctic Tern (and seventh recorded) was this adult at Canoa Ranch, Pima Co., 18 May 2020.

JWi; see Wilder 2020) and one at Buckeye, MAR, 17 Sep 2020 ( $\dagger$, ph. CS) were the only Chimney Swifts accepted. The status of this species in Arizona remains cloudy; it was well documented in small numbers in Tucson during the 1970s and early 1980 s, but only a few reports have been submitted since.

RUBY-THROATED HUMMINGBIRD Archilochus colubris $(0,7,1)$. An adult male at the Hassayampa River Preserve near Wickenburg, MAR, 12 Jul 2018 (ph. $\mathrm{MM}$ ) provided the eighth Arizona record.

PURPLE GALLINULE Porphyrio martinicus (4, 16, 4). Accepted records are of an adult along the Santa Cruz River, in Tucson, PIM, 11-17 Sep 2019 (KAs; ph. ML; ph. JMc; ph. NP; ph. PG; ph. LP); one at the Renaissance Drive pond in Tucson, PIM, 27 Jul-2 Aug 2020 ( $\dagger$, ph. JMc; ph. EB); one at a private residence on the Buenos Aires NWR, PIM, 3 Aug 2020 ( $\dagger$, ph. JS); and one on the University of Arizona campus in Tucson, PIM, 21 Aug 2020 (ph. DK). This species remains a casual late summer visitor to Arizona.

COMMON CRANE Grus grus $(0,1,1)$. After a one-year hiatus in 2018, one adult returned to Mormon Lake, COC, 11 May-9 Sep $2019(† L H)$ and again 9 May-13 Jul 2020 (ph. JWi). One adult with Sandhill Cranes (Antigone canadensis) at Willcox, COS, 28-29 Nov 2020 (AA; $\dagger$, ph. DD; $\dagger$, ph. CDB; $\dagger$, ph. GHR; Figure 2), provided a second Arizona record, under the inference that the three occurrences at Mormon Lake represent the same individual.

AMERICAN GOLDEN-PLOVER Pluvialis dominica (21, 35, 2). One was at Petrified Forest NP, APA, 11 Jun 2018 ( $\dagger$, ph. AB); one was at Lyman Lake SP near St. Johns, APA, 15 Oct 2018 (ph. CB). Though the ABC removed the American Golden- 
Plover from its review list in 2019, we continue to recommend care in distinguishing this species from the similar Pacific Golden-Plover (P. fulva), much rarer in Arizona.

NORTHERN JACANA Jacana spinosa $(0,5,2)$. One immature was discovered at a golf course pond in Green Valley, PIM, 8 Sep 2020 (ph. CB, DG) and later relocated about $2 \mathrm{~km}$ away at Canoa Ranch, PIM, 9-11 Sep 2020 (†, ph. CT; ph. PI; $\dagger$, ph. GHR; $\dagger$, ph. NP; $\dagger$, ph. BP; ph. PG; Figure 3$)$. An adult was along the Santa Cruz River in Tucson, PIM, 26 Sep 2020-9 Apr 2021+ (†, ph. JMc; ph. PI; $\dagger$, ph. NP; Figure 4). This species occurs regularly in Sonora as far north as Ciudad Obregon and Navajoa, about $480 \mathrm{~km}$ south of the Arizona border.

UPLAND SANDPIPER Bartramia longicauda $(3,10,2)$. One was in Tucson, PIM, 20 Aug 2020 (†MMS); another two were found the same day in Marana, PIM, 20 Aug 2020, remaining through 26 Aug 2020 ( $\dagger$, ph. JMc; $\dagger$, ph. MSk; $\dagger$, ph. EB). Most records in Arizona are from mid to late August.

RUDDY TURNSTONE Arenaria interpres $(2,11,1)$. One immature was at Yuma, YUM, 23 Aug 2019 ( $\dagger$, ph. BJ). In the $20^{\text {th }}$ century this species was more regular in Arizona during fall migration (see Rosenberg and Witzeman 1998), but there have been few records since it was returned to the review list in 2002.

BLACK TURNSTONE Arenaria melanocephala $(0,1,1)$. Arizona's second Black Turnstone was discovered at Yuma, YUM, 13 May 2020 ( $\dagger$, ph. HD; †, ph. GHR; Figure 5). One at Willcox, COS, 2 Jun 2005 (Stevenson 2005, Rosenberg et al. 2011) provided the only previous record. This species is fairly regular in small numbers at the Salton Sea, California (Patten et al. 2003).

RED KNOT Calidris canutus $(2,18,3)$. Single juvenile-plumaged birds were at Sacaton, PIN, 8 Sep 2017 ( $\dagger$, ph. DP); at Paloma Ranch, MAR, 31 Aug-3 Sep 2018 ( $\dagger$, ph. BJ, CS); and near Florence, PIN, 22 Sep 2018 (ph. DB). This species was encountered more regularly from the 1970s to 1990s (see Rosenberg and Witzeman 1998). It remains a casual migrant for which the $\mathrm{ABC}$ resumed reviewing reports in 2002.

RUFF Calidris pugnax $(0,10,3)$. Accepted records are of one at Aztec, YUM, 21 Oct 2019 (†, ph. GHR, DS); one at Stanfield, PIN, 20 Sep-7 Oct 2020 (KMi; †, ph. GHR; $\uparrow$, ph. PD); and one at Willcox, COS, 29 Sep-6 Oct 2020 (ph. EK; †, ph. NP). This species remains a casual visitor, last recorded in 2010 (see Rosenberg et al. 2019).

SHARP-TAILED SANDPIPER Calidris acuminata $(0,4,2)$. Two juveniles were found, one at Patagonia Lake SP, SCR, 28 Oct 2019 ( $\uparrow$, ph. JK) and another at Spot Road Farm, near Aztec, YUM, 29 Oct 2020 (HD; †, ph. GHR; †, ph. DB; Figure 6). All but one of Arizona's Sharp-tailed Sandpipers have been recorded from midOctober to early November.

WHITE-RUMPED SANDPIPER Calidris fuscicollis (0, 17, 3). Adult birds were at Gilbert Water Ranch, MAR, 3 Jul 2018 ( $\dagger$, ph. SF) and at Willcox, COS, 15-17 May 2019 (ph. KB) and 5 Jun 2020 ( $\dagger$, ph. DS; ph. EB). Most Arizona records are from mid-May to early June.

POMARINE JAEGER Stercorarius pomarinus $(2,8,2)$. Accepted records are of an adult at Roper Lake SP, near Safford, GRA, 21 Nov 2019 ( $\dagger$, ph. KW) and an immature at the Glendale recharge ponds, MAR, 28 Nov 2019 (ph. JR; ph. SB). The Pomarine is the jaeger most expected in Arizona so late in the fall, as there are only three records of the Parasitic after 1 October.

PARASITIC JAEGER Stercorarius parasiticus $(2,15,3)$. Juveniles were at Lake Havasu City, MOH, 10-23 Sep 2018 ( $\dagger$, ph. DVP; $\dagger$, ph. LHa; ph. MG) and at San Carlos Lake, GIL and PIN, 12-26 Sep 2018 (†, ph. TD). An adult was at Havasu Springs, LAP, 10 Nov 2018 (ph. JWe). Virtually all of Arizona's records of the Parasitic Jaeger are from September, the November bird being the latest ever. 
LONG-TAILED JAEGER Stercorarius longicaudus (0, 16, 2). A long-staying juvenile was at Lake Pleasant, YAV and MAR, 17 Sep-4 Oct 2019 ( $\dagger$, ph. MMc). An adult at the same location 18 Oct 2019 ( $\dagger$, ph. MMc) was the latest recorded in Arizona by 10 days (see Rosenberg et al. 2011).

BLACK-LEGGED KITTIWAKE Rissa tridactyla $(1,18,5)$. Single first-cycle birds were at Site Six launch ramp, Lake Havasu City, MOH, 3-11 Jan 2018 ( $\dagger$, ph. DVP); north of Willow Beach at Mile 60 along the Colorado River, Lake Mead NRA, MOH, 12 Dec 2018 (†GM); at Lake Havasu City, MOH, 21 Dec 2018-20 Jan 2019 ( $†$, ph. DVP; $\dagger$, ph. MG; $\dagger$, ph. TBn); and at Thunderbird Conservation Park, Glendale, MAR, 27 Dec 2018-1 Jan 2019 ( $\dagger$, ph. SF; ph. CR; $\dagger$, ph. SHo). An adult was at Upper Lake Mary near Flagstaff, COC, 18-25 Nov 2019 (ph. RS; †, ph. JWi). Most of the Arizona records are from mid-November to early January.

LAUGHING GULL Leucophaeus atricilla $(1,28,2)$. One first-cycle bird was at Lake Havasu, MOH, 14 Jan-16 Apr 2018 (BO; $\dagger$, ph. DVP; $\dagger$, ph. TBn), providing a first winter record for Arizona, and an immature was at Willcox, COS, 19-20 Apr 2018 ( $\dagger$, ph. JG). Most Arizona records fall between mid-March and late August. The ABC removed the Laughing Gull from its review list in 2018.

MEW GULL Larus canus $(0,26,2)$. One adult was at the north end of Lake Havasu, MOH, 11 Mar 2018 (†DVP), One first-cycle bird at Lake Havasu City, $\mathrm{MOH}, 18$ Nov $2018(\dagger$, ph. DVP) was probably the same individual as one there on 20 Jan 2019 ( $\dagger$, ph. MG; $\dagger$, ph. TBn) and on 21 Mar 2019 ( $\dagger$, ph. LHa). The Mew Gull is a casual late fall and winter visitor, most occurring along the Colorado River.

ICELAND GULL Larus glaucoides $(3,15,2)$. First-cycle individuals were at Lake Pleasant, MAR, 13-27 Nov 2018 ( $\dagger$, ph. MH; ph. CR) and at Roper Lake SP, near Safford, GRA, 7-17 Jan 2019 ( $\dagger$, ph. KW; ph. DVP). All Arizona records involve $L$. g. thayeri.

LESSER BLACK-BACKED GULL Larus fuscus $(0,11,10)$. Accepted records are of an adult at Willow Beach, Lake Mead NRA, MOH, 16 Sep 2018 ( $\dagger$, ph. BZ); an immature in the Bill Williams arm of Lake Havasu, MOH, 12 Nov 2019 ( $\dagger$, ph. DVP); a first-cycle bird at Roosevelt Lake, GIL, 14 Nov 2019 ( $\dagger$, ph. TD); a first-cycle bird at Lake Havasu City, MOH, 4 Jan 2020 (†, ph. DVP); a first-cycle bird at Lake Havasu City, MOH, 22 Sep 2020 ( $\dagger$, ph. KKa), and likely the same individual there 24 Oct 2020 ( $\dagger$, ph. VA); an adult at Lake Pleasant, MAR, 24 Sep 2020 (ph. CS); a first-cycle bird at Walnut Canyon Lakes, Flagstaff, COC, 15 Oct 2020 ( $\uparrow$, ph. DS); an adult at Meteor Crater Rest Area along I-40 east of Flagstaff, COC, 24 Oct 2020 (ph. JC; $\dagger$, ph. JWi); a first-cycle bird at the Glendale recharge ponds, MAR, 31 Oct 2020 ( $\dagger$, ph. PD); and a first-cycle bird at Lake Pleasant, MAR, 6-13 Nov 2020 (ph. $\mathrm{MMc} ; \dagger$, ph. ROD). This species' frequency in the western U.S. has increased greatly during the last decade; the first Arizona record was in 2006 (Rosenberg et al. 2011).

ARCTIC TERN Sterna paradisaea $(2,4,1)$. One adult at Canoa Ranch, PIM, 18 May 2020 (ph. CT; $\dagger$, ph. GHR; ph. BN; ph. PI; †, ph. NP; Figure 7) was almost certainly the same individual as the one $57 \mathrm{~km}$ to the north at Columbus Park, Tucson, PIM, 19 May 2020 (SR; $\dagger$, ph. GHR). It was the first Arctic Tern to be photographed in Arizona. Previous spring records were from mid-May to early June.

ELEGANT TERN Thalasseus elegans $(0,17,4)$. Two were at Amado, PIM, 1 May 2018 ( $\dagger$, ph. TR); two were at Willcox, COS, 10 Apr 2019 ( $\dagger$, s.r. REW); one was at the Glendale recharge ponds, MAR, 14 Mar 2020 (JR; $\dagger$, ph. MH; $\dagger$, ph. RR); and an unprecedented 12 birds were at Canoa Ranch, PIM, 19 May 2020 ( $\dagger$, ph. RWi). These last flew in, circled the small pond a few times, and departed, remaining for less than a minute! This species remains a casual spring and summer visitor.

WOOD STORK Mycteria americana $(3,10,2)$. One was at St. David, COS, 8 Sep 


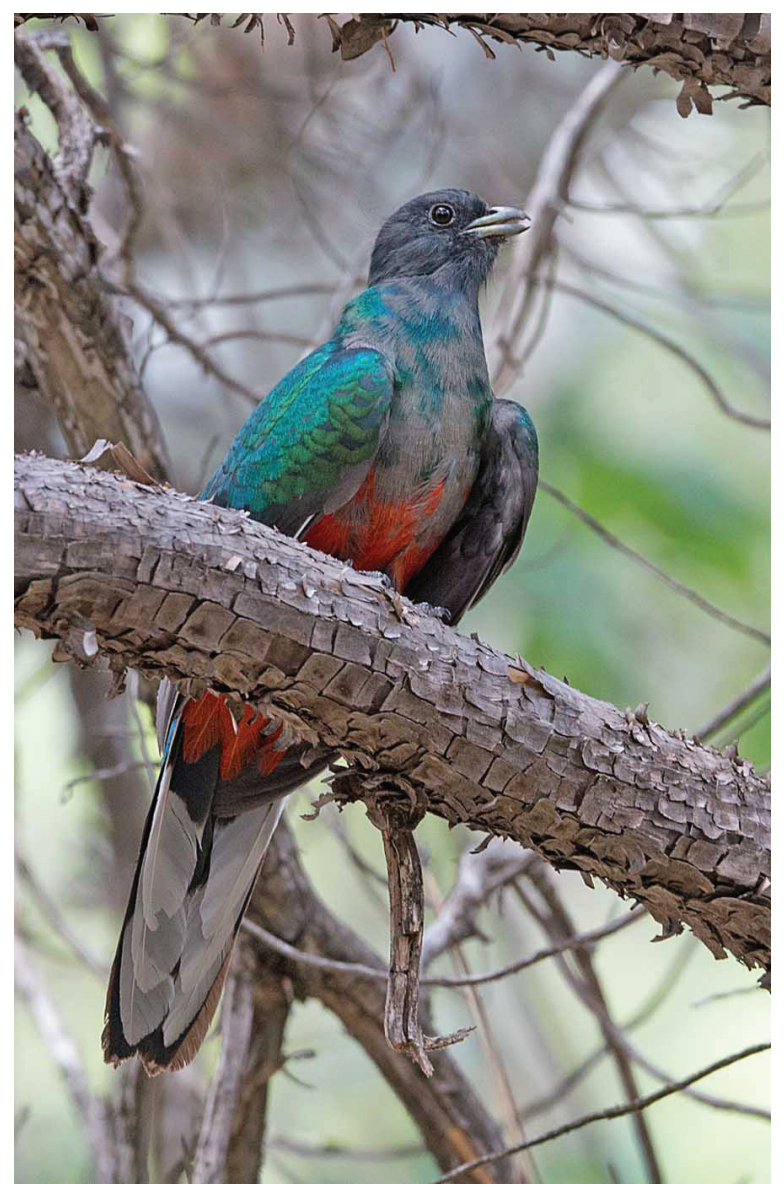

FIgure 8. This immature male Eared Quetzal was discovered along the Herb Martyr Road in Cave Creek Canyon, Chiricahua Mountains, Cochise County, 8-16 Jun 2020, and spent the summer and most of the fall wandering around the mountain range before settling back in Cave Creek Canyon, where it was last seen 25 November.

Photo by Bob Rodrigues

2018 (†, ph. LS); one was at Canoa Ranch, PIM, 22 Sep 2019 (†, ph. BN). Virtually all Arizona records fall between early June and mid-September.

MAGNIFICENT FRIGATEBIRD Fregata magnificens $(4,11,2)$. One was at Canoa Ranch, PIM, 30 Jul 2019 (ph. MSm); one was flying over I-10 in Green Valley, PIM, 18 May 2020 (ph. NB, RRe). Two additional reports, of one along Highway 80 near San Simon, COS, 18 Mar 2020 (ph. DO, DZ) and one at Yuma, YUM, 26 May $2020(† \mathrm{~GB})$, were accepted only as frigatebird (sp.). Given the several inland North American records of both the Great Frigatebird (F. minor) and Lesser Frigatebird (F. ariel) (see Sullivan et al. 2007), the ABC does not regard the Magnificent as the default frigatebird in Arizona. 


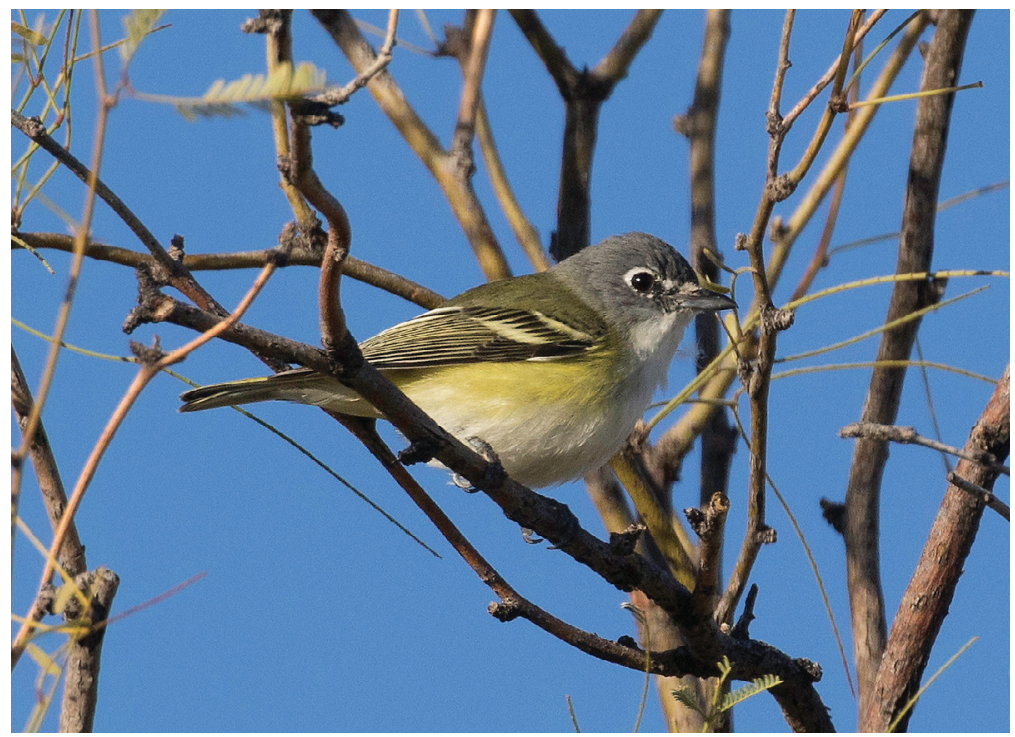

Figure 9. Arizona's fifth Blue-headed Vireo was this bird at Ajo, Pima Co., 9-10 Dec 2019.

Photo by Doug Buckland

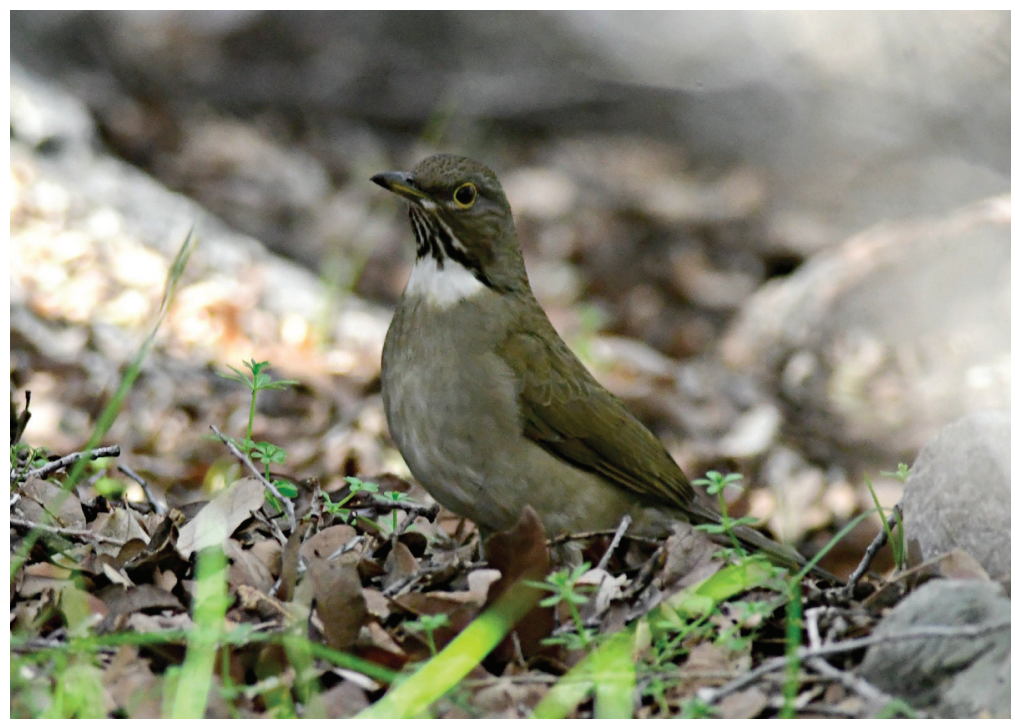

Figure 10. This White-throated Thrush in lower Madera Canyon, Pima Co., 9 Jan-20 Feb 2019 established a first Arizona record.

Photo by Mark Stratton 
BLUE-FOOTED BOOBY Sula nebouxii $(3,8,2)$. Accepted records are of one on Lake Havasu, MOH, 12-18 Sep 2018 ( $\dagger$, ph. LHa; ph. MG; ph. DVP) and one at Alamo Lake SP, LAP, 1-24 Nov 2019 (ph. SFo; $\dagger$, ph. JMc). The November record is the latest for Arizona record, as all of the previous Blue-footed Boobies were discovered between mid-July and late September.

GLOSSY IBIS Plegadis falcinellus $(0,19,4)$. Adults in breeding plumage were at Dome Valley, YUM, 30 May 2018 ( $\dagger$, ph. HD); at Paloma Ranch, MAR, 3 May 2020 ( $\dagger$, ph. PD); and at Willcox, COS, 20-29 May 2020 ( $\dagger$, ph. GHR, DS). One winter adult was at Vicksburg, LAP, 26 Sep 2020 (ph. CS). The ABC remains concerned about possible hybrids with the White-faced Ibis (P. chihi) being identified as pure Glossy Ibises.

EARED QUETZAL Euptilotis neoxenus (0, 25, 2). One, previously unreported, was in Gardner Canyon, SCR, 17 Apr 2015 (†KKa; v.r. PT). One immature male was along the Herb Martyr Road in Cave Creek Canyon, Chiricahua Mts., COS, 8-16 Jun 2020 ( $\dagger$, ph. PA, HS; ph. SW, CR, BR, GHR, PI, MMc, JMc; Figure 8), and a female was there 19 and 25 Jun 2020 (ph. RSe). Presumably the same two were discovered in Rucker Canyon on the west side of the Chiricahuas 16 Aug-7 Sep 2020 (†JA, LS; $\dagger$, ph. GHR). They returned to Cave Creek Canyon 15 Sep 2020, the male remaining until 25 Nov 2020 (ph. PI; ph. SW). The ABC is considering the male and female wandering around the Chiricahua Mountains in 2020 as one single record. Most of Arizona's 27 Eared Quetzals occurred during the 1990s; these records are the first since November 2013.

ROSE-THROATED BECARD Pachyramphus aglaiae (\#, 9, 6). A male along the Santa Cruz River, near Tubac, SCR, 20 Jan 2018 (ph. BM), was joined by a female, and the pair successfully nested and fledged young in early June 2018. Another male was at Rancho Santa Cruz, SCR, 23 Nov 2018 (ph. CDB). A female was near Tubac, SCR, 14 Jan 2019 (ph. BL); a male was there 4 May 2019 (ph. PG). A female found at the Patagonia-Sonoita Creek Preserve, SCR, 13 Jul 2019 ( $\dagger$ JSt) was feeding a fledgling there 4 Aug 2019 (ph. JMo); another female was along Blue Haven Road near Patagonia, SCR, 20 Apr-17 May 2020 ( †LD; †JK; †CSm). Rose-throated Becards have been along the Santa Cruz River between Tubac and Tumacacori almost continuously since at least 2017 , and several pairs are apparently nesting along this stretch of the river. The exact number of individuals this set of records substantiates is difficult to ascertain. The $\mathrm{ABC}$ had reinstated this species on the review list when it appeared to be absent from Arizona for more than a decade, but now that it is once again breeding (at least along the Santa Cruz River), we removed it from the review list again in 2020.

LEAST FLYCATCHER Empidonax minimus (3, 8, 3). One was near Sonoita, SCR, 17 Sep 2017 (ph. CSm); one was in Pasture Canyon, near Tuba City, COC, 23 Oct 2018 ( $\dagger$, ph. JWi; †CL); and one was at Dateland, YUM, 19-20 Sep 2020 (ph. CS; ph. BJ). This species remains a casual migrant in Arizona, with many of the records from mid-September.

BLUE-HEADED VIREO Vireo solitarius $(0,4,1)$. One was at Ajo, PIM, 9-10 Dec 2019 ( $\dagger$, ph. DBa; $\dagger$, ph. BN; Figure 9). Photos of that individual are definitive, perhaps the best documentation of the Blue-headed Vireo in Arizona to date, but potential confusion with bright-plumaged Cassin's Vireo ( $V$. cassinii) remains an identification problem.

PHILADELPHIA VIREO Vireo philadelphicus $(5,17,2)$. Accepted records are of one at the Boyce Thompson Arboretum, PIN, 20 Oct 2018 (†TC) and one near Kino Springs, SCR, 4 Oct 2020 ( $\dagger$, ph. RF). Most Arizona records are from October, 
and the ABC still cautions observers about possible confusion of the Philadelphia Vireo with bright-plumaged fall Warbling Vireos (V. gilvus).

RED-EYED VIREO Vireo olivaceus $(5,43,4)$. One was along Morgan City Wash, MAR, 13 Sep 2016 ( $†$ SF, TD); one was along the Santa Cruz River near Tumacacori, SCR, 21 Aug 2018 (ph. BL); one was at the Sweetwater Wetlands in Tucson, PIM, 27 May 2019 (†, s.r. MP); and one was along the Santa Cruz River near Tumacacori, SCR, 8 Oct $2019(\dagger \mathrm{LH})$. The ABC removed the Red-eyed Vireo from its review list at the end of 2019 .

YELLOW-GREEN VIREO Vireo flavoviridis $(1,13,4)$. One was along the Santa Cruz River near Tumacacori, SCR, 29 Jul-8 Aug 2018 ( $\dagger$, ph. BL; $\dagger$, ph. CMc); one was at Paton's Center in Patagonia, SCR, 5 Jul 2019 ( $\dagger$, s.r. KKa); one was at Empire Gulch, Las Cienegas National Conservation Area, PIM, 1 Aug 2019 ( $\dagger$, ph. CDB); and one was at the Hassayampa Preserve near Wickenburg, MAR, 15 Sep 2020 (ph. CS). Most of the Arizona records extend from June to August, the latest also being at Las Cienegas, 17 Sep 2017 (see Rosenberg et al. 2019).

CAVE SWALLOW Petrochelidon fulva $(0,10,1)$. An adult was at San Carlos Lake, PIN, GRA, and GIL, 18 Jun 2019 ( $\dagger$, ph. TD). Apart from the birds nesting in Tucson during the late 1970s and early 1980s (on the University of Arizona campus), all the other Arizona records have been during fall and winter.

BLACK-CAPPED CHICKADEE Poecile atricapillus (4, 9, 1). One was along Kanab Creek in Fredonia, COC, 21 Nov 2020 (ph. FG). Given the proximity of the nesting range in southwest Utah, the paucity of Arizona records might reflect a lack of coverage in the state's far north.

CAROLINA WREN Thryothorus ludovicianus $(0,4,1)$. One at Patagonia Lake SP, SCR, 8 Mar-25 Apr 2018 ( $\dagger$, ph. MB, TW; ph. MBg) provided a fifth record for Arizona. In New Mexico, this species has been found during the past decade at various locations along the Rio Grande.

WOOD THRUSH Hylocichla mustelina $(0,20,2)$. Accepted records are of one in Hunter Canyon, Huachuca Mts., COS, 6 Oct 2018 ( $\dagger$, ph. RWo) and one in Whitetail Canyon, Chiricahua Mts., COS, 14 Oct 2018 ( $\dagger$, ph. RTa). Most Arizona records are from fall between early October and early December.

WHITE-THROATED THRUSH Turdus assimilis $(0,0,2)$. Arizona's first Whitethroated Thrush was in lower Madera Canyon, PIM, 9 Jan-20 Feb 2019 ( $\dagger$, ph. LGr; ph. AC; $\dagger$, ph. MSt; ph. SHe; ph. BG; ph. FM; ph. PSv; Figure 10). A second bird was found in central Tucson, PIM, 28 May 2019 (ph. LJ; $\dagger$, ph. GHR; Figure 11). See Grant and Jenness (2020) for a summary of these two records. Previously, the species was known no closer than the Yecora area in central Sonora, about $400 \mathrm{~km}$ south of Madera Canyon.

CLAY-COLORED THRUSH Turdus grayi $(0,0,1)$. The first Clay-colored Thrush the $\mathrm{ABC}$ has accepted was a singing male at Arivaca Cienega, Buenos Aires NWR, PIM, 15-26 May 2020 ( $\dagger$, ph. MBl, SJ, DR; †, ph. GHR; ph. NP; †, ph. ROD; see Blackford et al. 2021; this issue's front cover). This species occurs regularly in the Rio Grande Valley, Texas, and it has been found in the Big Bend Region. The few extralimital records include one near La Cueva, New Mexico, 22 Nov 2001 (Williams 2007), representing the only New Mexico record; and one from El Dorado, Texas, 19 May 2012 (https://ebird.org/checklist/S10878730), well north of its normal range in Texas. Also, Rea and Hargrave (1984) identified the skull of a Clay-colored Thrush recovered from a packrat midden in Stanton's Cave, Grand Canyon, during an excavation in 1969. The skull was carefully distinguished from all other species of Turdus known from Arizona, the Rufous-backed (T. rufopalliatus) and White-throated as 


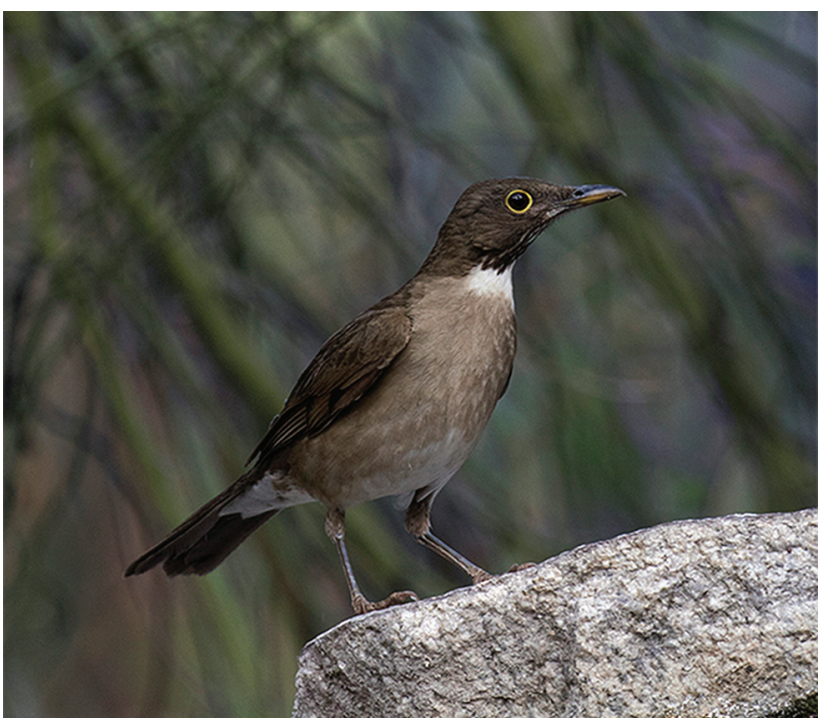

Figure 11. Arizona's second White-throated Thrush was in central Tucson, Pima Co., 28 May 2019.

Photo by Gary H. Rosenberg

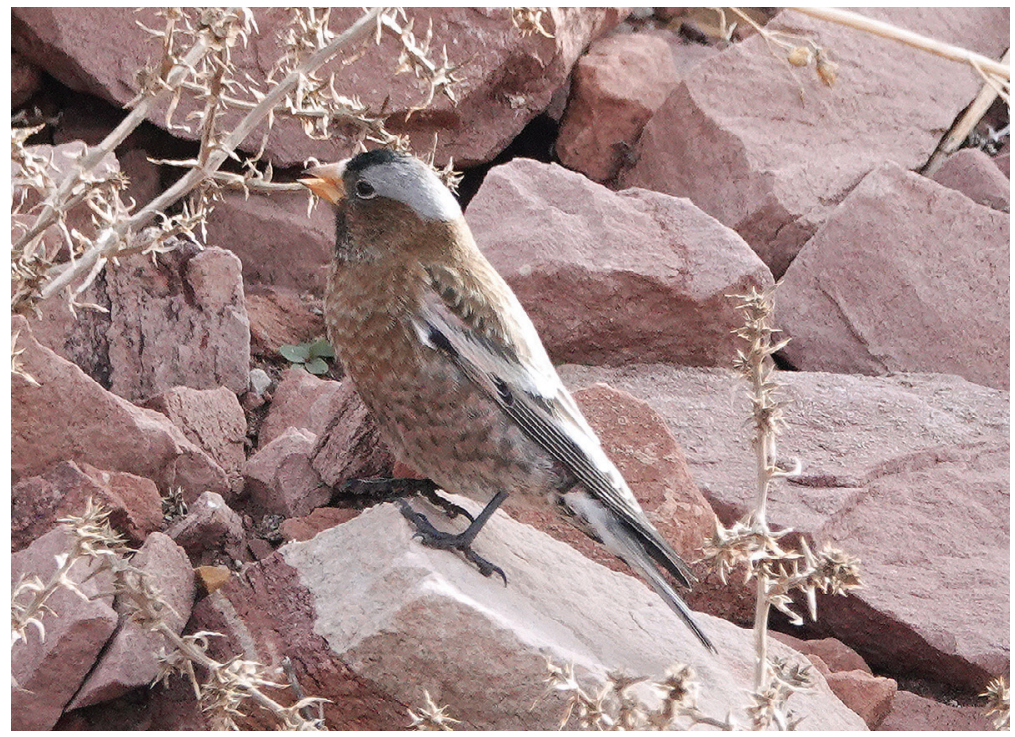

Figure 12. One of two Gray-crowned Rosy-Finches in a flock of 75+ Black RosyFinches at Echo Cliffs south of Page, Coconino Co., 9 Dec 2018-10 Mar 2019, representing the third record of the Gray-crowned for Arizona.

Photo by Jason Wilder 


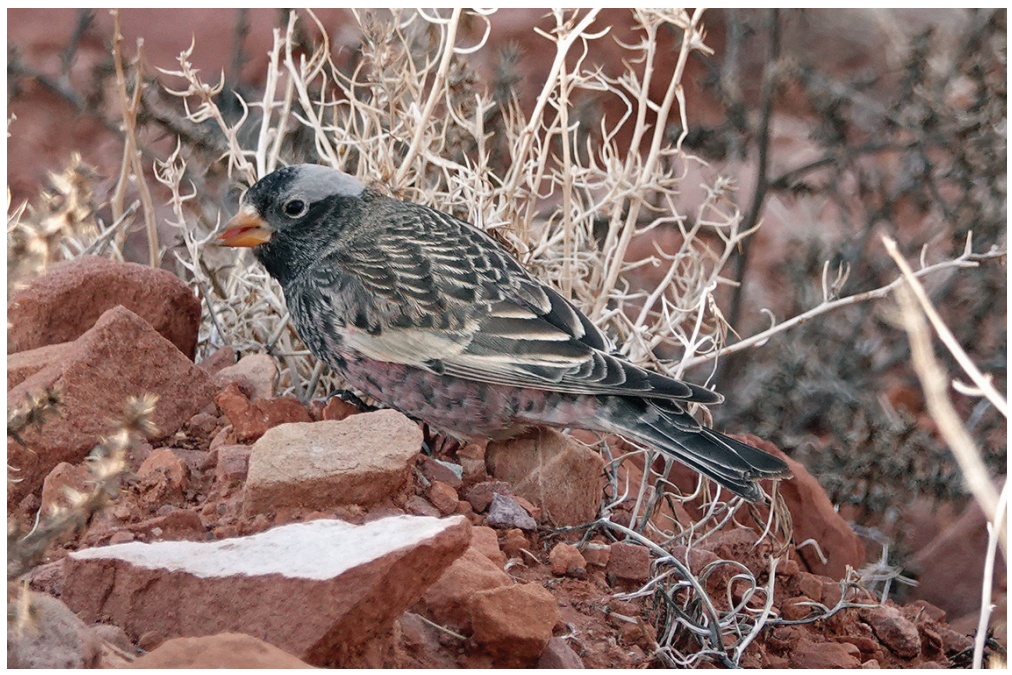

Figure 13. One of 75+ Black Rosy-Finches at Echo Cliffs south of Page, Coconino Co., 9 Dec 2018-10 Mar 2019, representing the seventh Arizona record of this species.

Photo by Jason Wilder

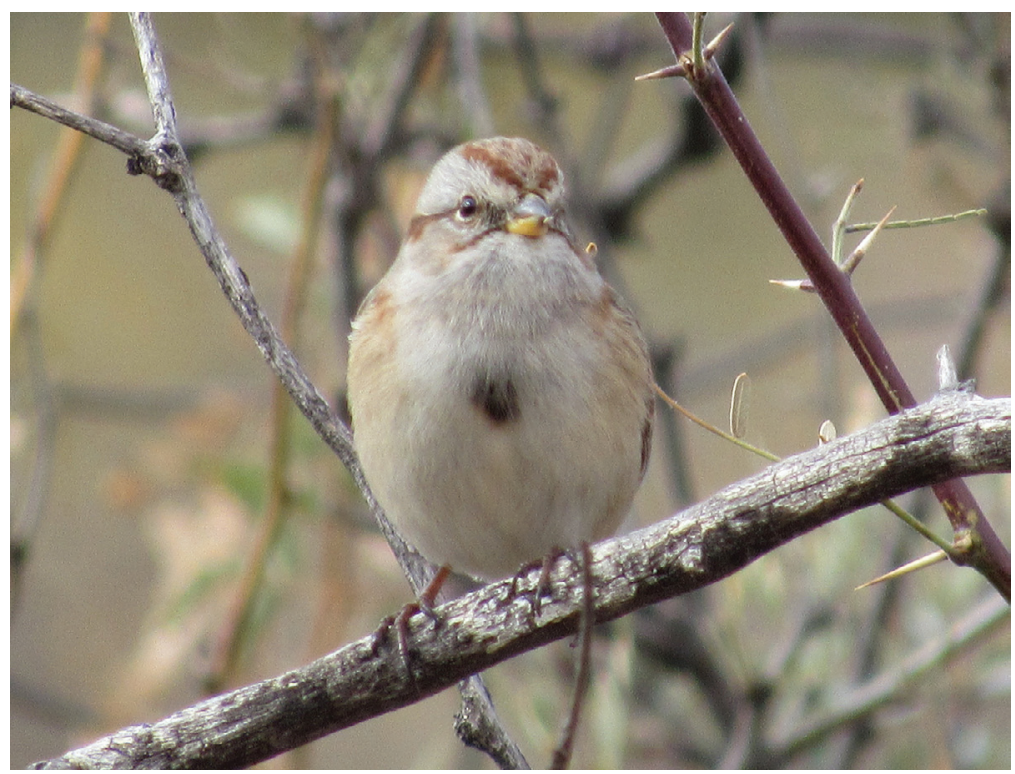

FIgURe 14. This American Tree Sparrow at Badger Springs, Agua Fria National Monument, Yavapai County, represented one of only a few southern Arizona records ever. 
well as the American Robin (T. migratorius), but its age is unclear, possibly as great as 40,000-80,000 years. The $\mathrm{ABC}$ is currently re-evaluating a previous report (photo) from Portal, COS, 21 Jun 2015, which had not been accepted because its provenance was questioned (Rosenberg et al. 2019).

GRAY-CROWNED ROSY-FINCH Leucosticte tephrocotis $(0,2,1)$. Two individuals were with a large flock of 75+ Black Rosy-Finches at the Echo Cliffs along Highway 89 south of Page, COC, 9 Dec 2018-10 Mar 2019 (CL; †, ph. JWi; †, ph. BJ; ph. DB; ph. CR; Figure 12). This species was not mentioned by Phillips et al. (1964); its inclusion on the Arizona list is based on 10 specimens collected at the Snow Bowl, near Flagstaff, between 16 and 25 February 1967 (Rosenberg and Witzeman 1999; http://eebweb.arizona.edu/Collections/Birds/Bird\%20Web/Specimen1. htm\#leucteph).

BLACK ROSY-FINCH Leucosticte atrata $(3,3,2)$. A flock of $75+$ Black RosyFinches was along the Echo Cliffs along Highway 89 south of Page, COC, 9 Dec 2018-10 Mar 2019 (ph. GN; ph. DB; ph. CR; ph. DRo; Figure 13), and up to three were there 3 Dec 2020-8 Jan 2021 (BJ; $\dagger$, ph. EB). A flock of $80+$ spent the winter of 1996-1997 at that locality (Rosenberg and Witzeman 1999). A flock of about 45 rosy-finches reported from the Vermilion Cliffs, COC, 1 Feb 2020 were identified as Black Rosy-Finches, but given the recent Arizona history of two species, and that the description did not conclusively differentiate one from the other, the $\mathrm{ABC}$ took a conservative position and considered them unidentified rosy-finches.

AMERICAN TREE SPARROW Spizelloides arborea $(\#, 7,2)$. One was at Round Rock, APA, 10 Dec 2020 (ph. FG); and one was at Badger Springs, Agua Fria NM, YAV, 14 Dec 2020-21 Jan 2021 (ph. AS; ph. PD; Figure 14). This species is a rare, somewhat irregular winter visitor to northern Arizona, and the $\mathrm{ABC}$ is interested in all reports of this species in the state.

FIELD SPARROW Spizella pusilla $(0,6,3)$. Accepted records are of one in Portal, COS, 17 Nov 2020 ( $\dagger$, ph. LC); one along the Santa Cruz River near Tumacacori, SCR, 19-20 Nov 2020 ( $\dagger$, ph. NM); and one at Whitewater Draw WMA, COS, 20-21 Nov 2020 ( $\dagger$, ph. SRo, RAB; ph. CR; Figure 15). All appeared to be examples of western S. p. arenacea, being noticeably grayer than eastern birds (see Rising 1996).

BOBOLINK Dolichonyx oryzivorus (\#, 21,2). One was at Joseph City, NAV, 18 Aug $2020(\dagger \mathrm{EH})$; one was at Whitewater Draw, COS, 7-10 Sep 2020 (†, ph. JMcL). This species is a casual visitor to Arizona, mostly in fall.

STREAK-BACKED ORIOLE Icterus pustulatus $(5,22,1)$. One was in central Tucson, PIM, 22 Jan-1 May 2018 (ph. LM; ph. JMe). The Streak-backed Oriole has proved to be a casual visitor (almost annual) to southern Arizona, with numbers of records increasing in recent years; the $\mathrm{ABC}$ discontinued reviewing it at the end of 2018 .

RUSTY BLACKBIRD Euphagus carolinus $(9,26,1)$. One was at a feedlot $4 \mathrm{~km}$ west-southwest of Red Rock, PIN, 31 Dec 2018 ( $\dagger$, ph. RF). In spite of the number of records accumulated, the $\mathrm{ABC}$ retains this species on the review list because of its similarity to Brewer's Blackbird (E. cyanocephalus).

COMMON GRACKLE Quiscalus quiscula $(0,38,2)$. Accepted records are of one at a private residence in Hereford, COS, 29 Oct 2018 ( $\uparrow, \mathrm{ph} . \mathrm{CHa})$ and one at a recreational-vehicle park $8 \mathrm{~km}$ north of Meteor Crater, COC, $21 \mathrm{Sep}-18$ October 2020 (CL; $\dagger, \mathrm{ph}$. JWi). This species has proven to be a casual visitor (almost annual) in Arizona, with numbers of records increasing in recent years; the $\mathrm{ABC}$ removed it from the review list at the end of 2020.

BLUE-WINGED WARBLER Vermivora pinus $(1,16,2)$. One was at Ramsey 
Canyon Nature Preserve, COS, 31 Aug 2019 (ph. KKo); one was at Joseph City, NAV, 26 Aug-3 Sep 2020 (TD; $\dagger$, ph. CMc). Arizona records are split about equally between spring and fall, with these two August records being the earliest in fall.

CRESCENT-CHESTED WARBLER Oreothlypis superciliosa $(0,15,1)$. An apparent pair (a second male was reported) was along West Turkey Creek on the west side of the Chiricahua Mts., COS, 27 Apr-11 July 2020 (DRa; †, ph. GHR; ph. BJ; ph. TL; $\dagger$, ph. BP; ph. CS; $\dagger$, ph. NP; Figure 16). Although present continuously through May and June, and observed nest-building on a few occasions, the birds did not appear to have fledged young. Nesting of the Crescent-chested Warbler has been reported in Arizona only once previously, on the basis of an adult seen feeding a fledgling along East Turkey Creek, Chiricahua Mountains, COS, 12-16 Jul 2007 (Rosenberg et al. 2011).

KENTUCKY WARBLER Geothlypis formosus $(3,34,6)$. One male was in Box Canyon, Santa Rita Mts., PIM, 15 Apr 2018 ( $\dagger$, ph. SP); one was near Petaluma, YUM, 19 May 2018 ( $\dagger$, ph. CMc); one was at Havasu NWR, MOH, 6 Jun 2018 ( $\dagger$, ph. CD); one was in Cave Creek Canyon near Portal, COS, 11 May 2019 ( $\dagger$, ph. EC); one was in Chandler, MAR, 2 May 2020 ( $\dagger$, ph. VB); and one was in the South Fork of Cave Creek Canyon, COS, 29 Sep 2020 ( $\dagger, \mathrm{ph}$. DDa). There are now well over 30 Arizona records, so the $\mathrm{ABC}$ removed the species from the review list at its January 2021 meeting.

CAPE MAY WARBLER Setophaga tigrina $(1,12,2)$. Accepted records are of one at the headquarters of Buenos Aires NWR , PIM, 29-31 May 2018 ( $\dagger$, ph. JS) and one in Surprise, MAR, 28 Sep-17 Oct 2020 (ph. JB; $\dagger$, ph. CKS). The one at Buenos Aires was only the second Cape May Warbler recorded in Arizona in spring.

TROPICAL PARULA Setophaga pitiayumi $(0,7,4)$. One was in Ramsey Canyon, COS, 9 Jun-29 Jul 2018 ( $\dagger$, ph. M\&CS); one was in Florida Canyon, Santa Rita Mts., PIM, 27 Aug-21 Sep 2019 ( $\dagger$, ph. DPa; ph. LH; $\dagger$, ph. AC); a singing male was in Huachuca Canyon, COS, 18-23 Jun 2020 (ph. JSl; †, ph. PI; †, ph. DB; †SC); and another singing male was in upper Ramsey Canyon, COS, 7-11 Jul 2020 (†, ph. SO, EO). Most Arizona records involved singing males in June and July.

BAY-BREASTED WARBLER Setophaga castanea $(0,21,2)$. One was along Proctor Road, Madera Canyon, PIM, 8 Dec 2019 ( $\dagger$, ph. ML); one was at Lake Pleasant, MAR, 2 Nov 2020 ( $† E H)$. Fall Arizona records extend from late September to early December, with most after mid-October.

BLACKBURNIAN WARBLER Setophaga fusca $(0,24,5)$. Accepted records are of one at Willow Lake, Prescott, YAV, 24 Sep 2019 ( $†$, ph. DM); another at Willow Lake, Prescott, YAV, 18 Sep 2020 (†DI); one at Gilbert Water Ranch, MAR, 28-30 Sep 2020 ( $\dagger$, ph. TLo; $\dagger$, ph. PD); one at Christopher Columbus Park, Tucson, PIM, 9-13 Nov 2020 ( $\dagger$, ph. CSh; $\dagger$, ph. GHR; ph. PI; $\dagger$, ph. NP; ph. SO); and one along the Santa Cruz River near Tumacacori, SCR, 13 Nov 2020 ( $\uparrow$, ph. CB). The 18 September record is the earliest fall record (by five days); most fall Arizona records range from late September to mid-October.

BLACKPOLL WARBLER Setophaga striata $(4,30,5)$. One, previously unreported, was at Maricopa, PIN, 15 Jun 2013 (ph. NB); an adult male was in Sycamore Canyon, SCR, 28 Apr 2018 ( $\dagger$, ph. JWi); one was in Oro Valley, PIM, 19 Sep 2019 ( $\dagger$, ph. TDJ); an immature was in Winslow, NAV, 22 Sep 2019 ( $\dagger$, ph. RF); and an adult male was at Holbrook, NAV, 20 May 2020 ( $\dagger$, ph. EH). As there are now more than 30 records, the $\mathrm{ABC}$ removed this species from the review list at the end of 2020.

PRAIRIE WARBLER Setophaga discolor $(3,15,3)$. One at Saguaro Lake, MAR, 5 Jan-3 Mar 2018 ( $†$ DW; ph. GK) returned 5-27 Mar 2019 and again for a third winter 21 Oct 2019. Other accepted records are of one in Rucker Canyon, COS, 16 


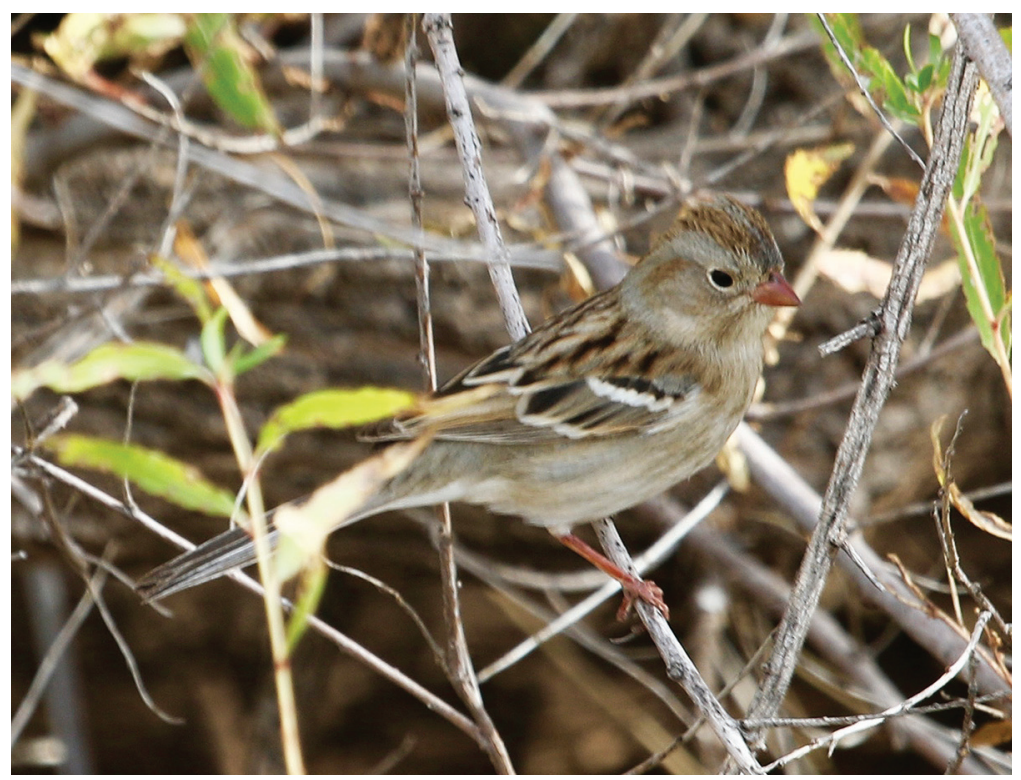

Figure 15. This Field Sparrow, at Whitewater Draw WMA, Cochise Co., 20-21 Nov 2020 was one of three in southern Arizona during the fall of 2020; there had been only six previous records.

Photo by Susan Rogers

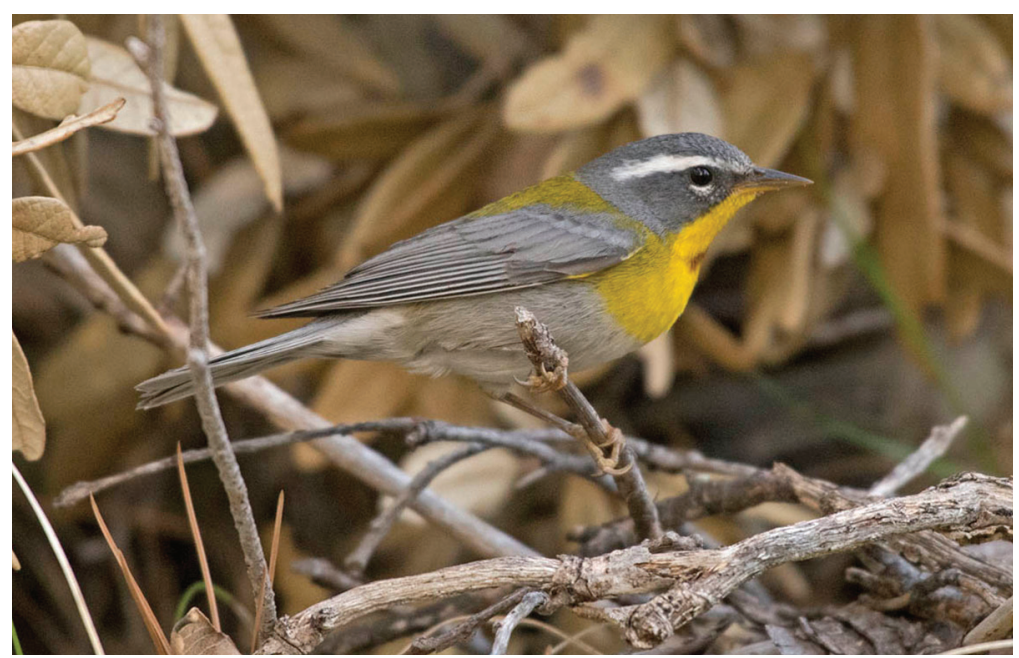

FIgURE 16. This Crescent-chested Warbler was one of at least two along West Turkey Creek, Chiricahua Mountains, Cochise County, 27 Apr-11 Jul 2020, where they attempted nesting, but were apparently unsuccessful in fledging any young. 


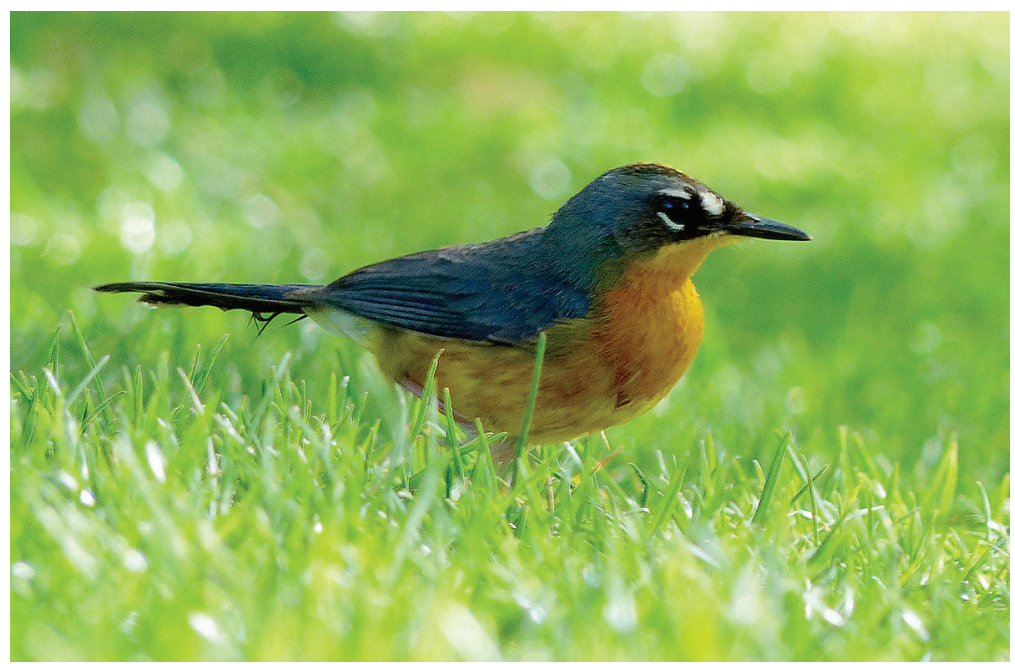

Figure 17. Arizona's 11th Fan-tailed Warbler was in Whitetail Canyon in the Chiricahua Mountains, Cochise Co., 13-18 Apr 2018.

Photo by Rick Taylor

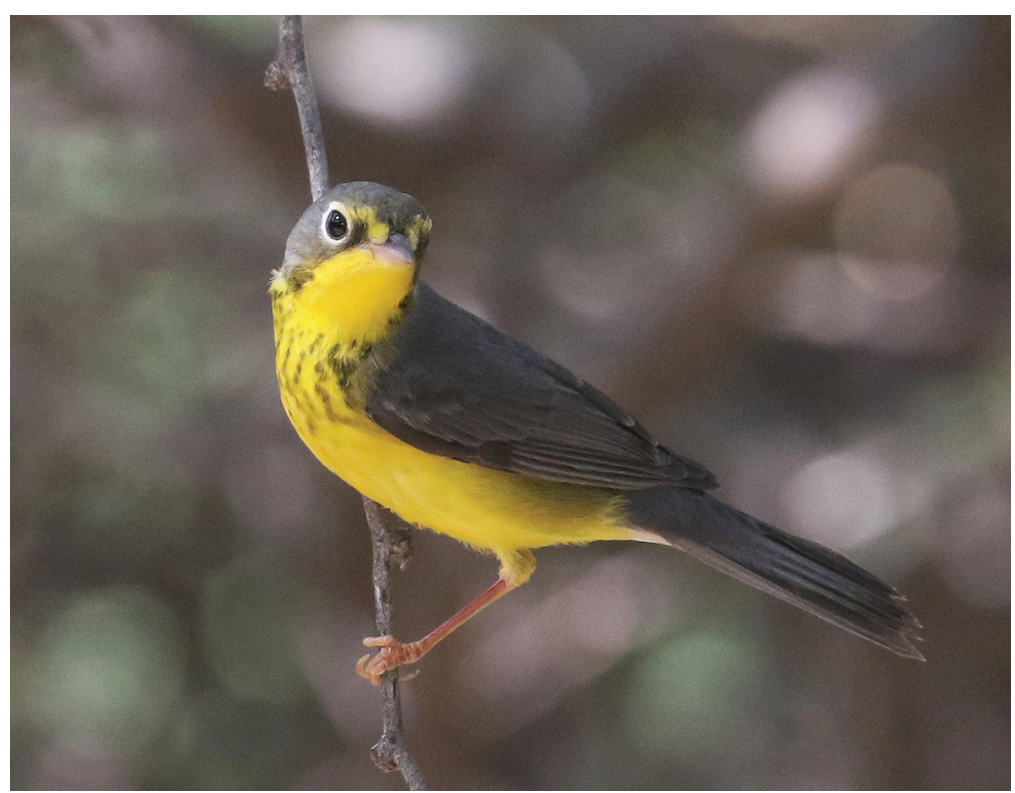

Figure 18. This Canada Warbler at Gilbert Water Ranch, Maricopa County, 12-15 Sep 2020 was one of three different Canada Warblers found in Arizona during the fall of 2020. 
May 2019 ( $\dagger$, ph. RAR, REW) and one at the headquarters of Buenos Aires NWR, PIM, 28 Sep-14 Dec 2019 (LN; $\dagger$, ph. AC; ph. JKi; eBird). A number of Arizona records are from late fall and winter, involving long-staying birds.

BLACK-THROATED GREEN WARBLER Setophaga virens $(7,27,5)$. One adult was in the South Fork of Cave Creek Canyon near Portal, COS, 10-11 Apr 2018 ( $†$, ph. D\&JP); an immature was along Tonto Creek near Tonto Basin, GIL, 17 Oct 2019 $(\dagger$, ph. TD); an adult male was at Northsight Park, Scottsdale, MAR, 24 Mar-13 Apr 2020 (ph. MVW); an immature was in Whitetail Canyon, Chiricahua Mts., COS, 10 Oct 2020 ( $\dagger$, ph. RTa); and one was in Peña Blanca Canyon west of Nogales, SCR, 22 Oct $2020(\dagger \mathrm{LD})$. There are more than 30 Arizona records, but because of potential identification issues with similar species and hybrids, the species remains on the review list.

FAN-TAILED WARBLER Basileuterus lachrymosa $(1,9,1)$. One was in Whitetail Canyon, Chiricahua Mts., COS, 13-18 Apr 2018 ( $\dagger$, ph. RTa; †, ph. NMC; ph. CR; ph. SH; $\dagger$, ph. AC; Figure 17). There are now 11 Arizona records of this Mexican species, most from May and June, the previous earliest being from Ramsey Canyon, COS, 7-10 May 2010 (see Rosenberg et al. 2017).

CANADA WARBLER Cardellina canadensis $(0,13,4)$. Two birds (apparently a male and female) were in Page, COC, 23 May 2020 (BBO, KS; $\dagger$, ph. RM), equaling the earliest spring record; one was at Gilbert Water Ranch, MAR, 12-15 Sep 2020 $(\dagger$, ph. HT, CDB; ph. MA; ph. MN; ph. JBu; ph. LP; Figure 18); one was at Box Bar Recreation Area, MAR, 16 Sep 2020 (ph. CS); and one was at Brandi Fenton Park, Tucson, PIM, 21-24 Oct 2020 ( $\dagger$, ph. SO; $\dagger$, ph. GHR; ph. CR; ph. PI; ph. PG; †, ph. NP). This species is a casual visitor to Arizona in both late spring and fall.

FLAME-COLORED TANAGER Piranga bidentata (0, 21,3). One (likely returning) male was in upper Ramsey Canyon, COS, 9 Apr-5 Aug 2018 (ph. JA); a female was in Ash Canyon, Huachuca Mts., COS, 12 Apr 2020 ( $\dagger$, ph. RAB); and a male was in upper Miller Canyon, COS, 19 May-17 Jun 2020 (LD; $\dagger$, ph. TH). A majority of Arizona records come from either the Santa Rita or Huachuca mountains.

YELLOW GROSBEAK Pheucticus chrysopeplus $(1,24,1)$. An apparent female was along the Santa Cruz River near Tubac, SCR, 28 May 2019 ( $\dagger$, ph. BL). Most Arizona records are from mid-May to mid-August.

\section{NON-ACCEPTED REPORTS}

NORTHERN JACANA Jacana spinosa. A report of an apparent immature at Arivaca Lake, PIM, 7 Sep 2020 was intriguing, given the record of one in Green Valley, PIM, the following day (see above), but the description lacked critical details, such as any mention of yellow in the wings, and the flight was described as "heron-like," leading to most on the committee voting to not accept this written description.

BLACK SKIMMER Rynchops niger. A report of one at Tempe Town Lake, MAR, 18 Nov 2018 lacked critical details and received little support from the committee.

WHITE IBIS Eudocimus albus. One reported seen "briefly" by an experienced observer near Wellton, YUM, 26 Aug 2020 received a mixed vote; the description (and view of the bird) lacked any mention of either the bill or legs.

RED-HEADED WOODPECKER Melanerpes erythrocephalus. The description of one from Harshaw Canyon, outside Patagonia, SCR, 17 Dec 2020 suggested a very brief sighting and lacked convincing details.

MILITARY MACAW Ara militaris. An old photo of two "green-colored" macaws, from "up to seven" reported at Patagonia, SCR, 23 August 1992 was intriguing, but 
they were regarded by some on the committee as not identifiable to species, and no further details were available for evaluation. The ABC remains concerned as well about possible escaped macaws. This species is known to wander from its breeding areas, as close as $160 \mathrm{~km}$ south of the border, so it certainly might occur as a wild vagrant in Arizona (D. Vander Pluym pers. comm.).

LEAST FLYCATCHER Empidonax minimus. Photographs of an Empidonax at Patagonia Lake SP, SCR, 23 Jan 2019 did not eliminate Hammond's Flycatcher (E. hammondii).

EASTERN WOOD-PEWEE Contopus virens. One was reported from Gilbert Water Ranch, MAR 23 May 2019, but not by the original observer, and photos of a Contopus seen later that day were inconclusive.

RED-EYED VIREO Vireo olivaceus. Photographs of a vireo at Tres Rios Wetlands, Tolleson, MAR, 14 Aug 2018 were inconclusive.

CAROLINA WREN Thryothorus ludovicianus. A report of one "heard only" at the Patagonia-Sonoita Creek Preserve near Patagonia, SCR, 4 Dec 2018 was insufficient for identification. The $\mathrm{ABC}$ could not evaluate the report of the unseen bird without a voice recording.

STREAK-BACKED ORIOLE Icterus pustulatus. Photographs of a bird identified as this species from Tucson, PIM, 10 May 2018 were of an immature Bullock's Oriole (I. bullockii).

RUSTY BLACKBIRD Euphagus carolinus. A report of one with Yellow-headed Blackbirds near McNeal, COS, 31 Jan 2019 lacked critical identification details, and the circumstances of the sighting seemed odd for a Rusty Blackbird in Arizona.

\section{CONTRIBUTORS}

Peg Abbott, Jane Addis, Vernie Aikins, Marsh Alphonso, Aaron Ambos, Jesse Amesbury, Richard Aracil, Keith Ashley (KAs), Seth Ausubel, Doug Backlund (DBa), Kenneth Bader, Julie Barnhill, Cathy Beck (CB), Robert A. Behrstock (RAB), Chris D. Benesh (CDB), Nancy Bent, Deanna Bibbee, Maureen Blackford (MBl), Geoffrey Bland, Valerie Boman, Harold Bond, Derik Bowen (DBo), Erin Bowen, Steve Boyack, Andy Bridges, Mark Brogie (MBg), Matt Brown (MBr), Jim Burns $(\mathrm{JBu})$, Marissa Buschow, Ed Conrad, Lori Conrad, John Coons, Andrew Core, Troy Corman, Charles Corson, Scott Crabtree, Debra Davison (DDa), Tommy DeBardeleben, Timothy DeJonghe (TDJ), Thomas Benson (TBn), Henry Detwiler, Pierre Deviche, Chris Dodge, Louie Dombroski, Diane Drobka, Sean Fitzgerald, Sally Foster (SFo), Richard Fray, Brendan Galvin, Joel Gilb, Pat Goltz, Linda Grant (LGr), David Griffin, Kathleen Groschupf, Lisa Grubbs, Matthew Grube, Felipe Guerrero, Carla Hall, Laurens Halsey (LH), Chris Harbard (CHa), Lauren Harter (LHa), Kay Hawklee, Stuart Healy (SHe), Melanie Herring, Karen Herzenberg (KHe), John Hirth, Tonya Holland, Steve Hosmer (SHo), Eric Hough, Sam Hough, Patricia Isaacson, Diane Iverson, Lynn Jacobs, Sally Johnsen, Brian Johnson, Eric Kallen, Keith Kamper (KKa), Gordon Karre, Dalton Kelahan, Adam Kent, Simon Kiacz, Joanne Kimora (JKi), Kordeen Kor (KKo), Jim Krakowski, Chuck LaRue, Max Leibowitz, Tom Lindner, Bill Lisowsky, Tyler Loomis (TLo), Jennie MacFarland (JMc), Curtis Marantz (CM), Janine McCabe (JMc), Chris McCreedy (CMC), Chet McGaugh (CMG), Michael McGee, Barry McKenzie, Josh McLaughlin (JMcL), Mary McSparen (MMc), Jeremy Medina (JMe), Linda Merrick, Greg Meyer, Kent Miller (KMi), Jake Mohlmann (JMo), David Moll, Nick Moore, Narca Moore-Craig (NMC), Francis Morgan, Ken Murphy, Gerry Nealon, Muriel Neddermeyer, Larry Norris, Brittany O'Connor, Ryan O’Donnell (ROD), Erin Olmstead, Scott Olmstead, 
Parker O'Neil, BB Oros (BBO), Brian Nicholas, Damian O'Sullivan, David Palmer (DPa), Debby \& Jim Parker (D\&JP), Bryan Patrick, David Pearson, Levi Plummer, Molly Pollock, Steven Prager, Nick Pulcinella, Dylan Radin (DRa), Sarah Ramsey, Diane Rand, Roger Reason (RRe), Ronnie Reed, Jeff Ritz, Bob Rodrigues, Susan Rogers (SRo), Chris Rohrer, David Rosenberg (DRo), Gary H. Rosenberg (GHR), Terry Rosenmeier, Kristen Rothrock, Rose Ann Rowlett (RAR), Mike and Corinne Schall (M\&CS), K. Schroeck, Larry Scritchfield, Ryan Seppala, Cathy Sheeter (CSh), Eric Sibbald, Jonathon Sleger (JSl), Michael Skinner (MSk), Chrissy Kondrat-Smith (CKS), Curtis Smith (CSm), Joshua Smith, Matt Smogor (MSm), Helen Snyder, Adam Stein, David Stejskal, Mark M. Stevenson (MMS), Laura Stewart, Caleb Strand, Mark Stratton (MSt), Justin Streit (JSt), Paul Suchanek, Peder Svingen (PSv), Rick Taylor (RTa), Patty Tersey, Craig Thayer, Holly Thomas, Renee Tressler, David Vander Pluym (DVP), Marceline VandeWater (MVW), Kyle Waites (KWa), Richard E. Webster (REW), John West (JWe), Kathy West (KWe), David Wiedenfeld, Jason Wilder (JWi), Richard Willot (RWi), Steve Wolfe, Diane Wong-Kone (DWK), Tom Woods, Robert Woodward (RWo), Kelly Wright, Dawn Zappone, Ben Zyla.

\section{ACKNOWLEDGMENTS}

We thank the more than 185 observers who submitted material to the AZFO and $\mathrm{ABC}$; they have made an important contribution to our expanding knowledge of the status of Arizona birds. Thanks to reviewers Steve Heinl and Dan Gibson, who both contributed greatly to the improvement of the manuscript. Philip Unitt also improved the manuscript.

\section{LITERATURE CITED}

Blackford, M., Johnsen, S., and Rand, D. 2021. First Arizona Clay-colored Thrush record. Arizona Birds 2021; https://arizonabirds.org/journal/2021/arizonabirds-clay-colored-thrush.pdf.

Brown, D. E. 1989. Arizona Game Birds. Univ. Ariz. Press, Tucson.

Grant, L., and Jenness, D. 2020. Arizona's first and second records of White-throated Thrush. Arizona Birds 2020; https://arizonabirds.org/journal/2020/arizonabirds-white-throated-thrush.pdf.

Hamilton, R. A., Patten, M. A., and Erickson, R. A. (eds.). 2007. Rare Birds of California. W. Field Ornithol., Camarillo, CA.

Monson, G., and Phillips, A. R. 1981. Annotated Checklist of the Birds of Arizona, 2nd ed. Univ. Ariz. Press, Tucson.

Patten, M. A., McCaskie, G., and Unitt, P. 2003. Birds of the Salton Sea. Univ. Calif. Press, Berkeley; doi.org/10.1525/9780520929449.

Phillips, A., Monson, G., and Marshall, J. 1964. The Birds of Arizona. Univ. Ariz. Press, Tucson.

Rea, A. M., and Hargrave, L. L. 1984. The bird bones from Stanton's Cave, in The Archaeology, Geology, and Paleobiology of Stanton's Cave, Grand Canyon National Park, Arizona (R. C. Euler, ed.), pp. 79-91. Grand Canyon Nat. Hist. Assoc. Monogr. 6.

Rising, J. D. 1996. A Guide to the Identification and Natural History of the Sparrows of the United States and Canada. Academic Press, San Diego.

Rosenberg, G. H. 2001. Arizona Bird Committee report: 1996-1999 records. W. Birds 32:50-70.

Rosenberg, G. H., and Witzeman, J. L. 1998. Arizona Bird Committee report, 1974-1996: Part 1 (non-passerines). W. Birds 29:199-224. 
Rosenberg, G. H., and Witzeman, J. L. 1999. Arizona Bird Committee report, 1974-1996: Part 2 (passerines). W. Birds 30:94-120.

Rosenberg, G. H., Radamaker, K., and Stevenson, M. 2007. Arizona Bird Committee report, 2000-2004 records. W. Birds 38:74-101.

Rosenberg, G. H., Radamaker, K., and Stevenson, M. 2011. Arizona Bird Committee report, 2005-2009 records. W. Birds 42:198-232.

Rosenberg, G. H., Radamaker, K., and Vander Pluym, D. 2017. Arizona Bird Committee report, 2011-2015 records. W. Birds 48:74-112; doi.org/10.21199/WB48.2.1.

Rosenberg, G. H., Vander Pluym, D., and Halsey, L. 2019. Arizona Bird Committee report, 2015-2017 records. W. Birds 50:150-175; doi.org/10.21199/WB50.3.3.

Speich, S. M., and Parker, T. A. III. 1973. Arizona bird records, 1972. W. Birds 4:53-57.

Speich, S. M., and Witzeman, J. L. 1975. Arizona bird records, 1973, with additional notes. W. Birds 6:145-155.

Stevenson, M. 2005. First occurrence of Black Turnstone in Arizona. Arizona Birds Online 2:1-3; https://arizonabirds.org/journal/2005/arizona-birds-firstoccurrence-black-turnstone.pdf.

Sullivan, B. L., Iliff, M. J., Ralph, P. L., Ralph, C. J., and Kelling, S. T. 2007. A Lesser Frigatebird (Fregata ariel) in California: A first for the state and fourth for North America. N. Am. Birds 61:540-545.

Tinsman. J., and Meyers, M. 2019. Nevada Birds Records Committee report for 2017. W. Birds 50:2-15; doi.org/10.21199/WB50.1.1.

Wilder, J. 2020. Documentation and identification of northern Arizona's first record of Chimney Swift. Arizona Birds 2020; https://arizonabirds.org/journal/2020/ arizona-birds-first-record-chimney-swift.pdf.

Williams, S. O. III. 2007. Fifth report of the New Mexico Bird Records Committee. NMOS Bull. 31:61-65. 